H

16-2)

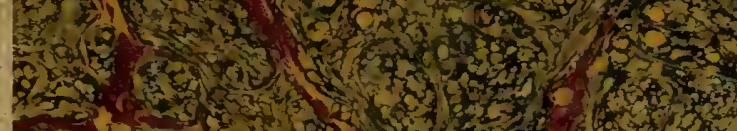

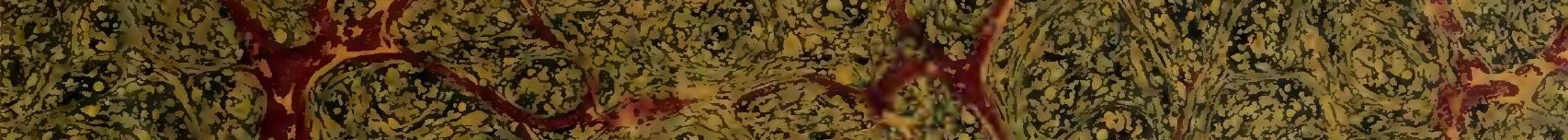

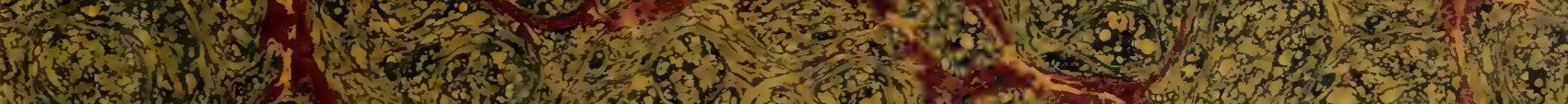

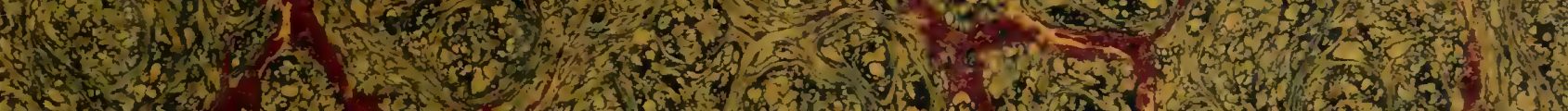

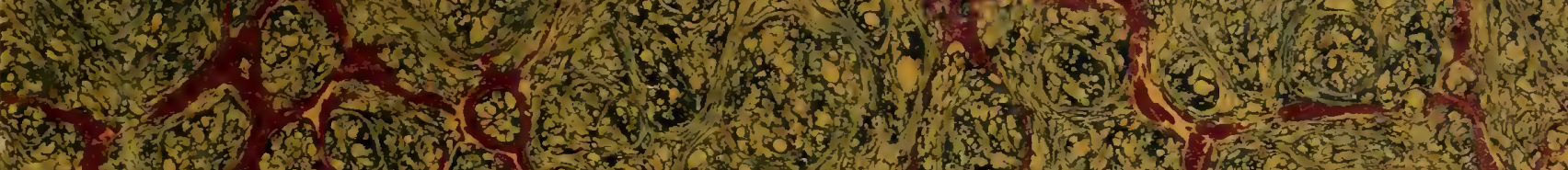

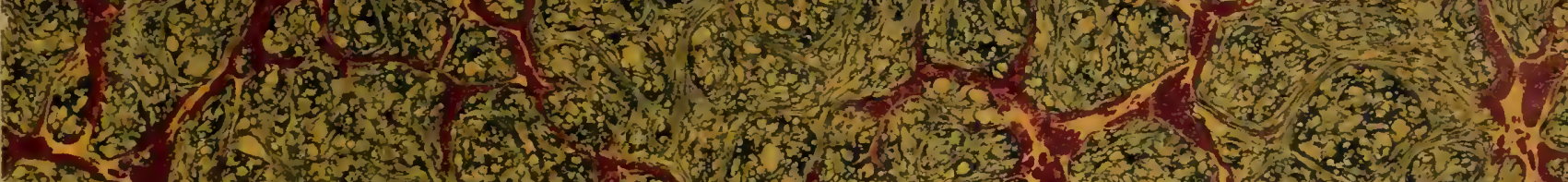

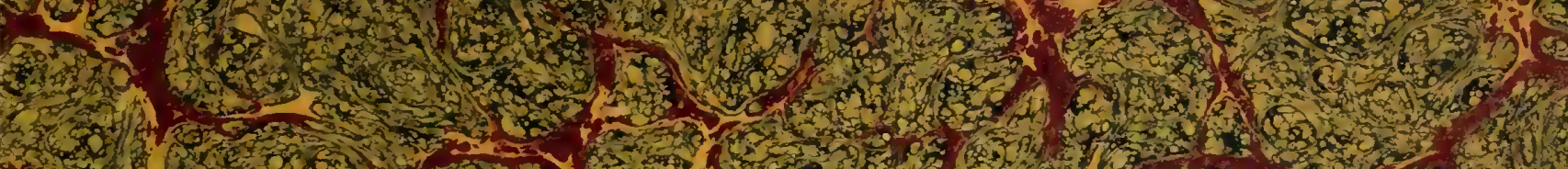

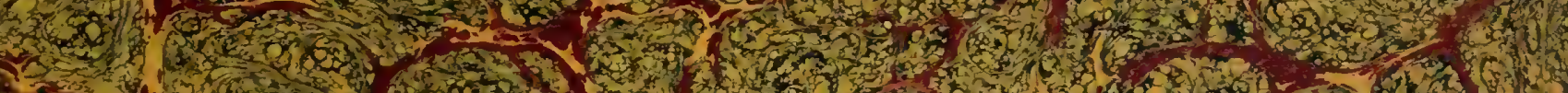

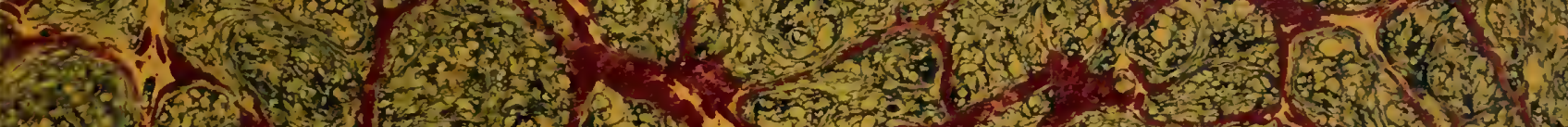

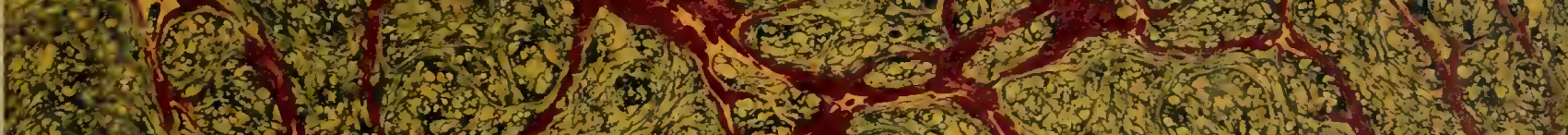

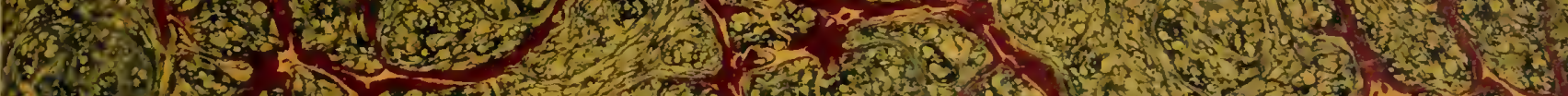

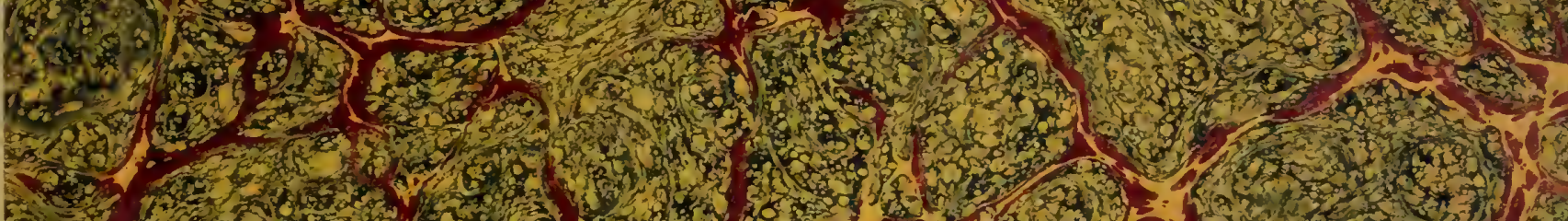

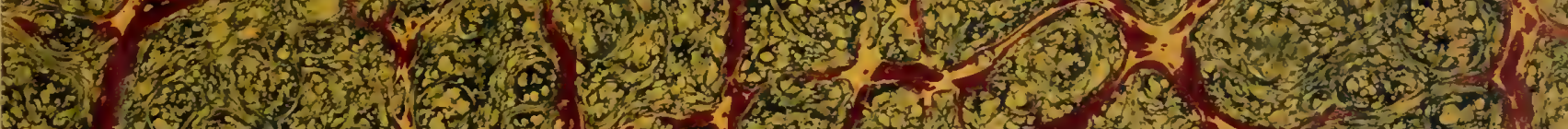

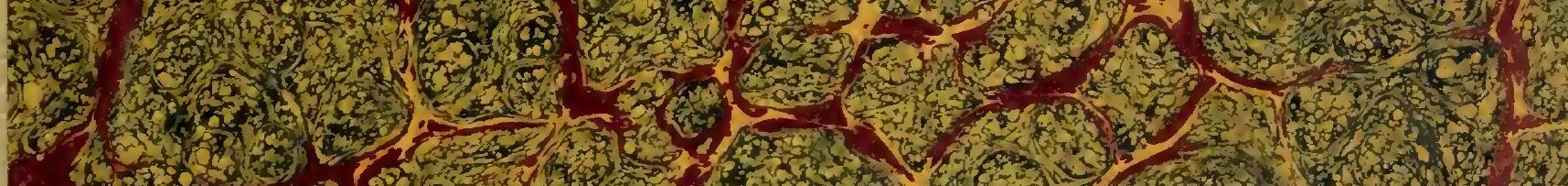

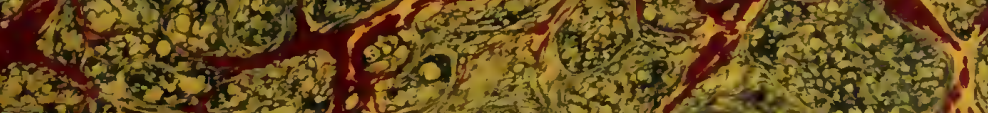

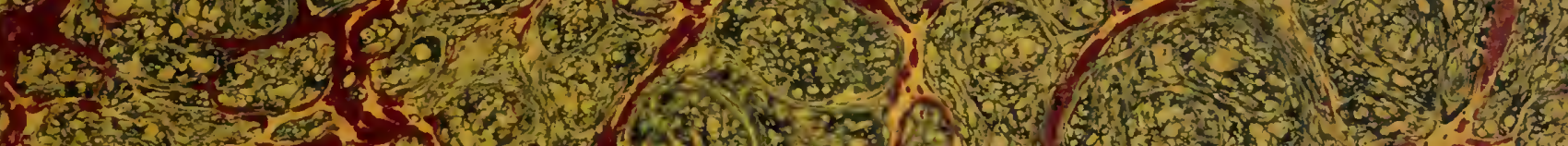

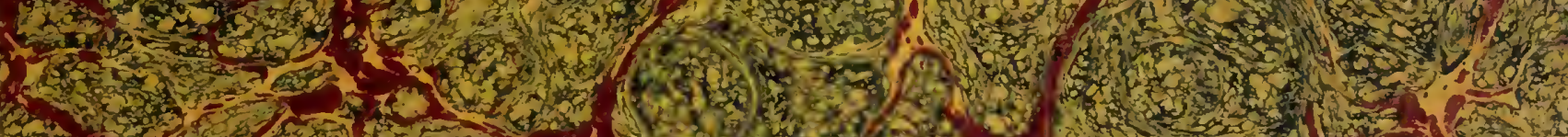

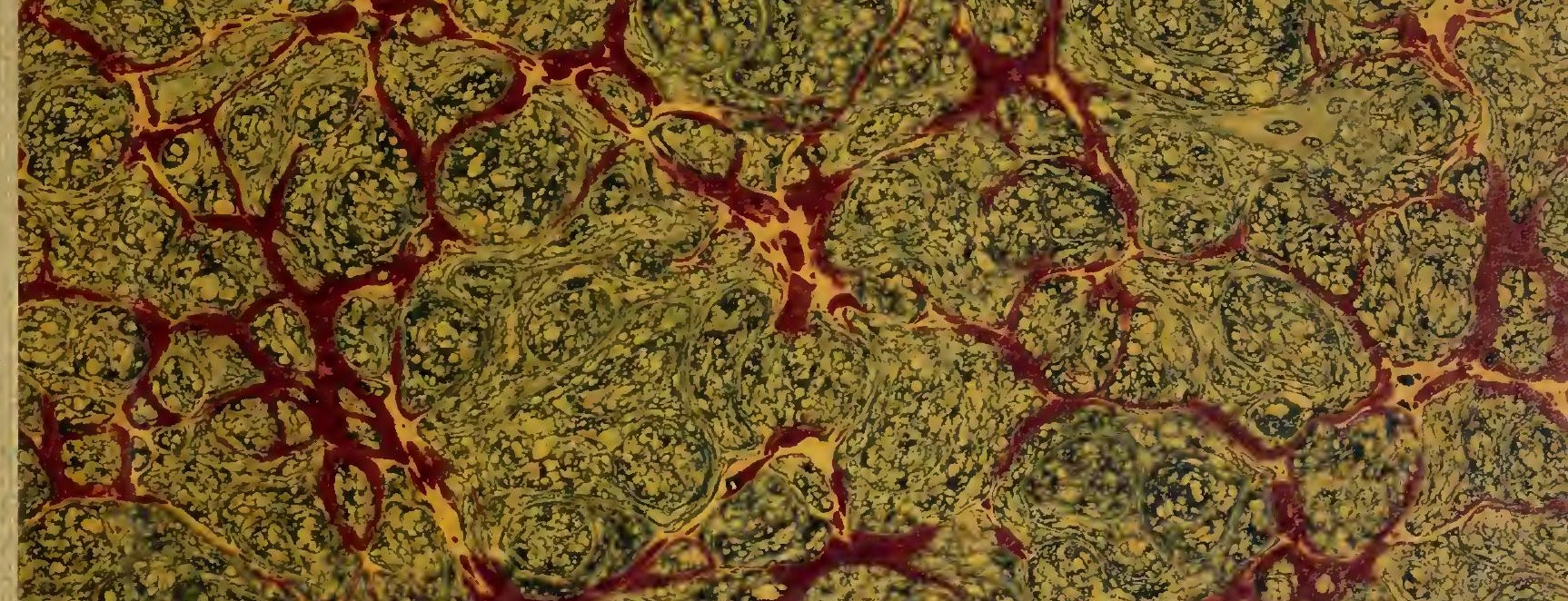

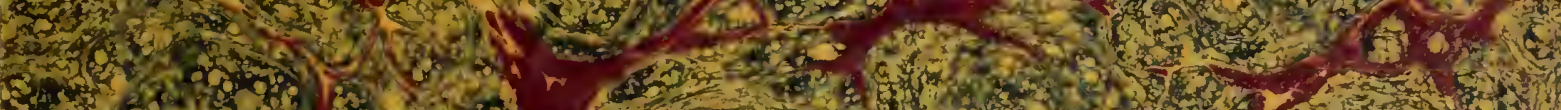

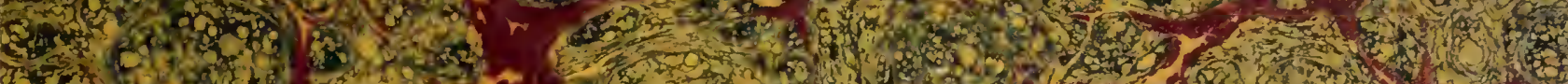

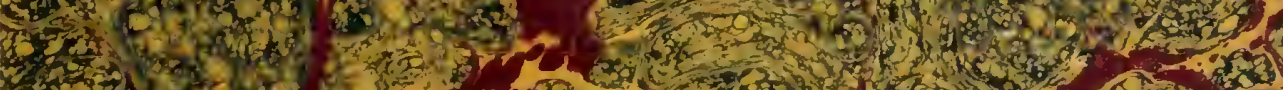

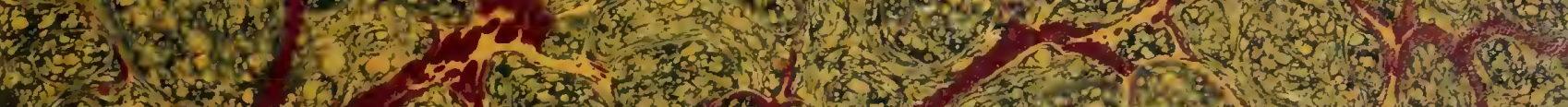

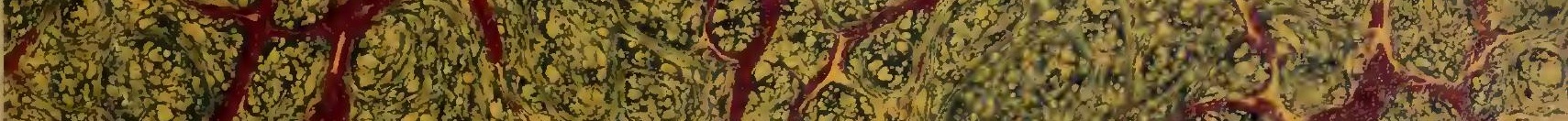

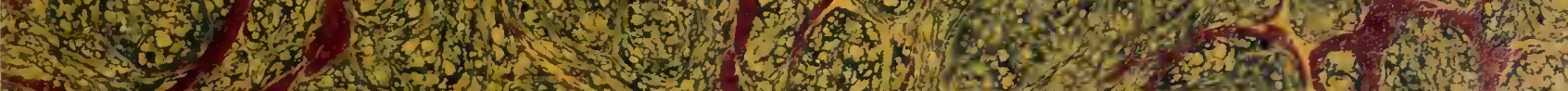

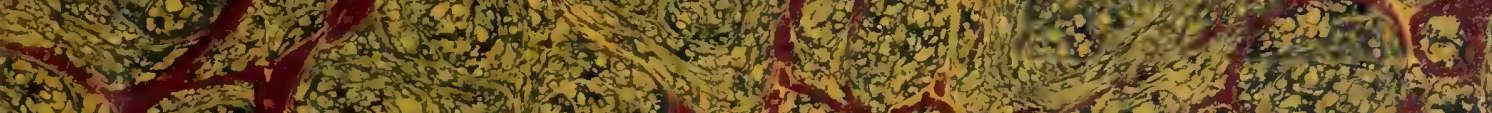

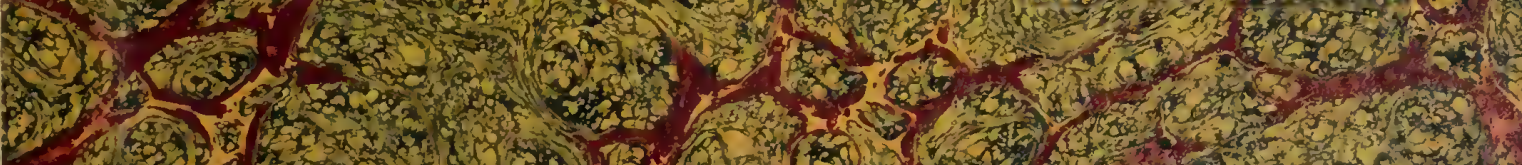




\section{HARVARI) UNIVERSITY.}

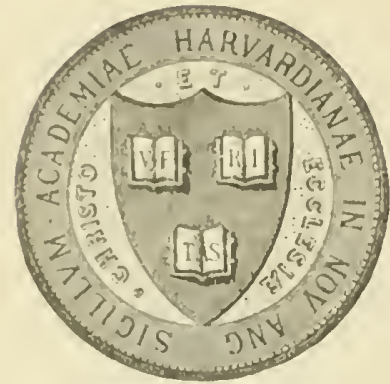

$$
\begin{aligned}
& \text { I,IBRARY } \\
& \text { OF THE }
\end{aligned}
$$

MUSEUM OF COMPARATIVE ZOOLOGY 22,510

GIFT OF

$$
\text { ALEXANDER AGASSIZ. }
$$

Sforember, $24.190 z$ 


\title{
PHILOSOPHICAL TRANSACTIONS
}

OF THE

\section{ROYAL SOCIETY OF LONDON.}

\author{
Series B, VOL. 196, pp. 99-118.
}

\section{ON THE EVOLUTION OF THE PROBOSCIDEA.}

$\mathrm{BY}$

C. W. ANUREWS, U.Sc., F.G.S., BRITISH MUSEUM (NATURAL HISTORY).

\section{- LON DON :}

PUBLISHED FOR THE ROYAL SOCIETY BY DULAU AND CO., 37, SOHO SQUARE, W. CONTINENTAL AGENTS, MESSRS. FRIEDLÄNDER AND SON, BERLIN.

$$
\text { -1903. }
$$
B. 217.

$$
\text { Price One Shilling. }
$$



iviv $z+i+n^{2}$ 

IV.-On the Einolution of the Proboscider.

By C. W. Andrews, D.Sc., F.G.S., British Musenm (Natural History).

Communicated by Prof. Ray Iankester, F.R.S.

Received March 5,-Read March 26, 1903.

The Proboscidea form one of the most isolated groups of the mammalia, for although it is now generally recognised that they belong to the Ungulata, they nevertheless differ widely from all other members of that order. They are further remarkable for the fact that, while in some respects, e.g., in their large size and peculiar dentition, they are among the most specialised of mammals, in others, as, for instance, in the structure of their feet, they are relatively very primitive. The history of such an isolated group is necessarily of exceptional interest, and the peculiarities of the animals themselves render it the more easy to follow the course of their development, because the danger of confusing them with allied types is to a great extent eliminated; furthermore, in scarcely any other group can the phylogenetic history be traced back through so long a series of forms.

Until quite recently the earliest Proboscidea known were from the lowest Miocene beds (Burdigalien) of France, where they are represented by at least two species, viz., Dinotherium cuvieri and Tetrabelodon angustidens.* In somewhat later deposits these two genera Dinotherium and Tetrabelodon oceur widely distributed in Europe and as far east as India. Tetrabelodon angustidens has also been recorded from the northern part of the Libyan Desert and from Morocco. The group seems to have reached North America during the Miocene, and the earliest recorded species is found in the Upper Miocene beds of Montana. This form has been described by Core under the name Tetrabelodon brevidens; it is remarkable for the simplicity of its molars. Dinotherium is not found in any American deposits. The Mastodons did not penetrate into South America till the Pliocene. The absence of Dinotherium from America and the circumstance that the teeth of Tetrablodon brevidens are at least as simple as those of any European species, suggests the possibility that the Proboscidea may have reached North America not by way of Europe, but along some independent land connection. 'The absence of the dinotheroid type might also be accounted for by the

* This name is here adopted in preference to the more usual one, Mastodon angustidens, beeause there can be no doubt that this animal is generically distinct from the Mastodon americanus for which the genus Mustodon was founded by Curier, and falls within the genus Tetralelodon as defined lyy Cope.

TOL. CXCVI. - B. $21 \%$.

о 2

13.8.03. 
finct that those anmals were very heavily huilt and probably semi-anuatic, so that their spreald into new areas may have been rery slow and perhaps was checked by lanriers that would unt interfere with the T'etrabelolonts.

The firct that no remains of Proboscileans have been found in any pre-Mincene deposit of Europe, Asia or North America shows clearly that the group camot have minginated in any of those continents, but must have arisen on some adjacent landarea, from which also several other fomilies, appearing for the first time in the European Mincene, may have been derived, and various speculations as to the position of this land-area have been put forwarl. Among later writers the hypothesis that the Ethiopian region was the centre of distribution of the Proboscidea has been

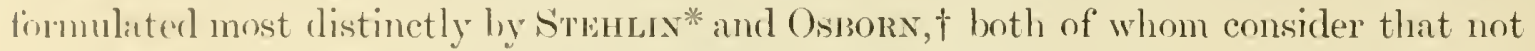
only the Proboscidea, hut also a mumber of other groups such as the Hyracoidea, the Orycteropodide, the antelopes and the giraffes are of African origin; and to these

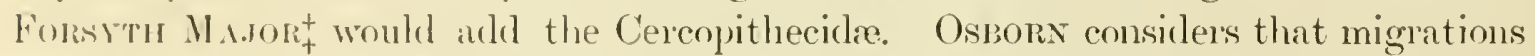
from Africa into the Eurasian continent have occurred on several occasions, notably towirds the end of the Encene, at the beginning of the Mincene and at the beginning of the Plincene. On this hypothesis it must have been during the early Mincene immigration that the Proboscidea reached the northern region, probably along some land comnection establisherl at the commencement of the great earth movements that culminated in the formation of the Alpine momntain system.

'The accuracy of the hypothesis of an Ethiopian centre of distribution of the Probnscidea has been filly demonstrated during the last two years by the discovery of a number of primitive members of the sub-order in the Middle and Upper Encene heds of the Filyum district of Egypt, where they occur associated with remains of other mammals, especially of early Hyracoidea, as well as of some remarkable reptiles. 'The great interest of this discovery will be recognised when it is considered that in the paper by Professor Ossors, above referred to, Africa is spoken of as "the dark continent of palreontology, for it has practically no fossil mammal history." The material for at least the begimning of such a history is now arailable, and it is to he hoped and expected that within the next few years much will be added to it.

The Proboscidea so far collected from Egypt are: (1) From the Middle Encene, Mcoritherium (three species) and Barytherium; (2) fiom the Upper Eocene, Palromastolon and perhaps Arsinoitherimm. The presence in these beds of so considerahle a

* Stenlı, "Ueher die Geschichte des Suirlen-(iehisses," II Theil ; “Ah. d. Schweiz. Palieont. Gesellscluaft.,' vol. 2$\rceil$ (1900), p. $4 \pi$ i et seq.

† Osbonx, "Correlation between Tertiary Mammal Horizons of North of Europe and America," 'Ann. N.Y. Acad. Sci.,' rol. 13, pp. 1-72, 1900.

† 'Geological Magarine,' Dec. 4, vol. 3 (1896), p. 436.

$\$[. J 11 y, 1903$. Since this was written, remains of a species of Derithrinum have been found by IIr. Beansel, and myself in the L Lper Eocene beds, where, however, they are very rare. On the other haud, no trace of I'aleromatstudon has been found in the Midllle Eocene.] 
number of Proboscideans of such diverse forms, points to the conclusion that they were a predominant Eocene type in this region, and that probably many other peculiarly modified members of the group are still to be found. Furthermore, from the presence of a gigantic form like Burytherium in the Middle Eocene beds, it seems clear that still earlier types are to be sought in the Lower Eocene.

Of the genera mentioned above, Palcomastodon and Mceritherium appear to be on the direct line of the ancestry of the Elephants and Mastodons, and will be described below. Arsinoitherium, if indeed it is a Proboscidean at all, is an extraordinarily specialised and aberrant type, and appears to have left no descendants. Barytherium shows some similarity to the Dinotheriidxe in the structure of its teeth, and may be nearly allied to those animals, though probably not their direct ancestor. Barytherium also shows certain likeness to those remarkable South Anerican mammals, the Pyrotheriidie, which have been described by Ameonino, who regards them as Proboscideans of Cretaceous age. This writer has lately published a paper* in which he seeks to trace back the Proboscidea through a long series of genera to a group of Jurassic mammals, the Microbiotheriidæ, apparently closely allied to the Didelphiidre. While it seems possible that some of the forms described by AmeaHiso are actually Proboscideans, and that there was a land connection between Africa and South America in older Tertiary times, as for various reasons has been considered probable by many writers, nevertheless it is difficult to accept his views as to the age of the beds in which these remains occur, and it seems far more likely that the Pyrotherium-beds are Tertiary rather than Cretaceous. Anegnivo further considers that Moritherium and Barytherium form side branches and are not on the main line of descent of the later elephants. The whole question of these South American forms is at present so obscure that, for the purposes of the present paper, they may be ignored and attention directed to the Old-World genera only.

In following out the course of the evolution that has taken place in a group of mammals we may either begin with the later more specialised forms and then pass backward to the earlier and simpler members of the series, or the reverse. In the present communication it is proposerl to adopt the former alternative, since in this case it is particularly interesting to note the persistence with which modification along certain lines has taken place and to show that by following back in time the known Post-Tertiary and Neogene species it would have been almost possible to predict that the earlier terms of the series would present precisely the character which we now find actually existing in the Middle and Upper Eocene genera, Mneritherium and Palcemustodon.

It is not now intended to enter into details of the evolution of the group even were this possible, but merely to take four stages, so as to show the general trend of the modification that has taken place. The numerous intermediate stages between

* "Linea Filogenetica de los Proboscideos," 'Anales del Mnseo Nacional de Buenos Aires,' Tom. VIII (Ser. 3, tom. 1), 1902, p. 19, et seq. 
the Mastodoms and the true Elephants fommel among the fossil Proboscidea of the Siwalik llills have leen described by several writers (sce, for instance, 'Falenner's Palleontologienl Memoris') and will therefore be omitted, as also will be many of the species that seem to stand apart from the main line. In some of these latter certain chatracters sem to have remained almost unchanged, while others have undergone molification along the same lines as in the rest of the gromp. An example of this is

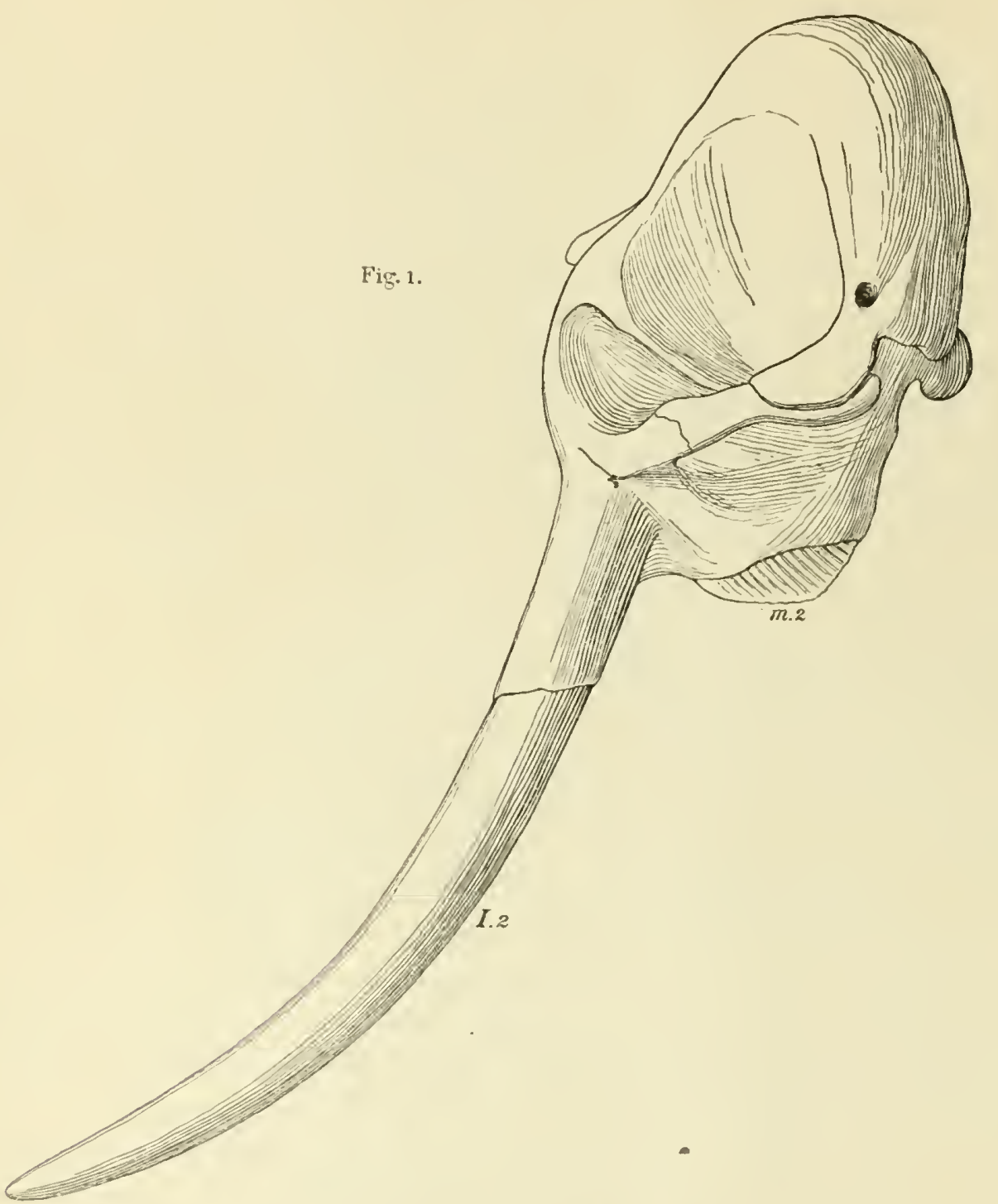

Fig. 1, - Sknil of Eilephus murimus, Inxwats. Recent. India.

scen in Mastodon americanus which survived till the Pleistocene; in this animal the molar tecth have remained in a condition of simplicity that would not be out of place in a Mincene species, while at the same time the symphysis of the manclible has heen shortened to almost the same extent as in the Elephants (figs. 4 and 5).

The representatives of the stages of erolution to which attention is here directed 
may be taken as (1) Elephas maximus; (2) Tetrabelorlon angustidens; (3) Palaomastodon beadnelli; (4) Moritherium lyonsi. The greatest gap is between the first and second nembers of this series, but, as already pointed out, this is to a great extent bridged over by a number of species, more especially fiom the Siwaliks; some of these species have been placed in an intermediate genus, Stegodon.

'The skull and mandible with the dentition are of course the most important portions of the skeleton for the purpose in view, but some reference is made to one or two other points.

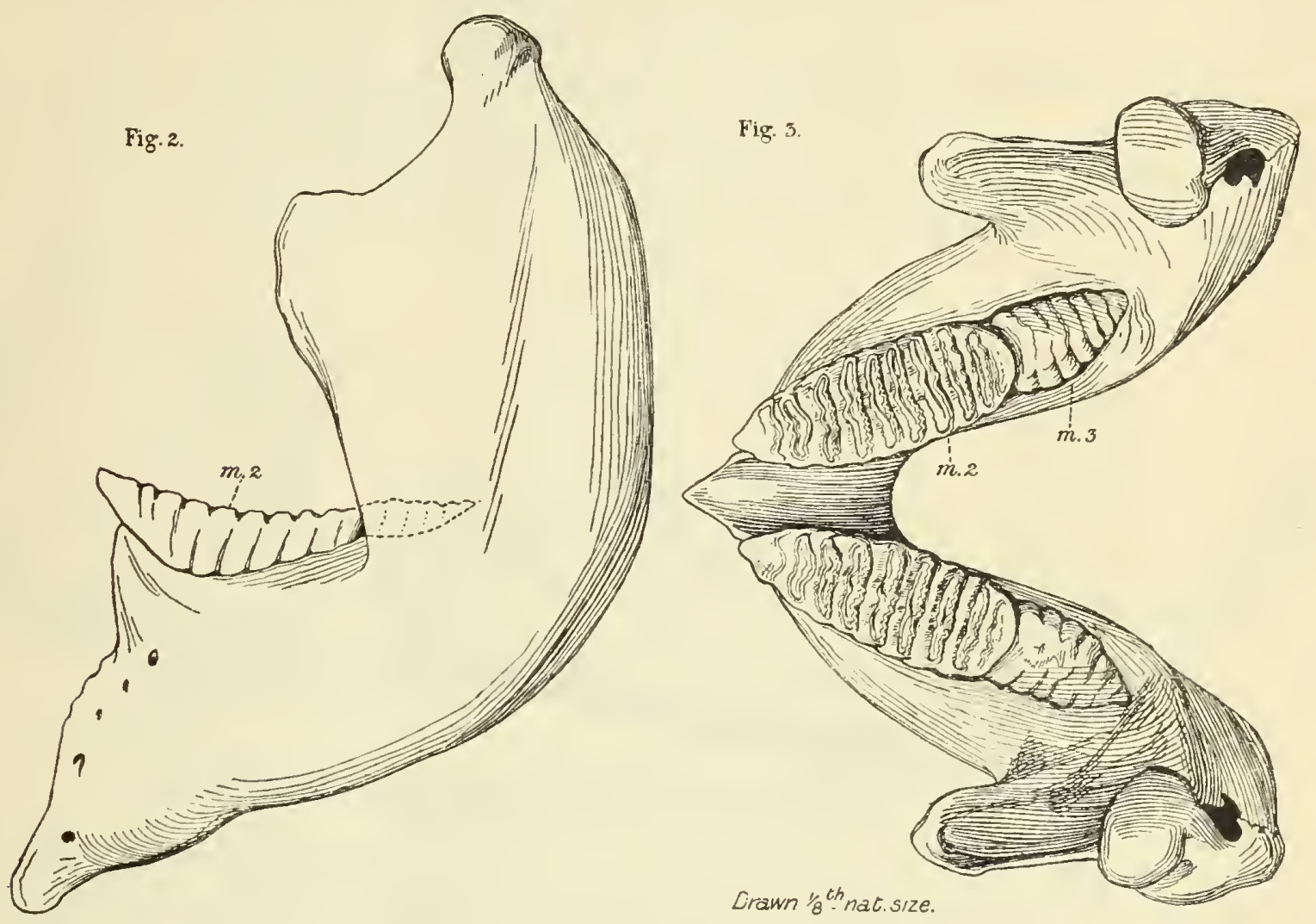

Figs. 2 and 3.-Mandible of Elephes marimus, Lixxaus. Recent. India.

Elephus maximus, LINseus. (E. indicus, CUVIER.)

The Skull (fig. 1). - The chief peculiarities of the skull of the elephant are due to the great size of the molar teeth and their mode of succession, and also to the weight of the tusks and trunk. 'The latter finctor" accounts for the enormous extension of the occipital surtace which is brought about by the development of the diploë to an extent unparalleled in other mammals. The bones chiefly affected are the parietals and squamosals, but most of the other bones of the skull present the same peculiarity to a greater or less extent. 'The consequence is that the region usually occupied by the lambdoidal crest is here expanded into a large mass of bone which forms attachinent 


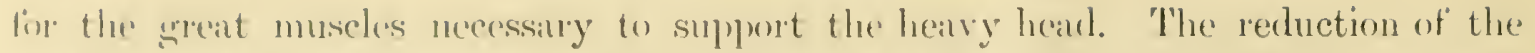
masil bones and the posterion position of the external nares is due to the presence of the probuseis, which also accomts for the width and concavity of the premaxillae

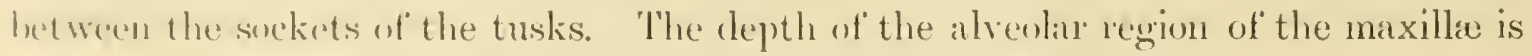
lue to the large size and peculiar mode of sucession of the molars.

'There is no prost-erlenoid process, hut a broal post-tympanic process of the squamosal morets the hinder bonder of the ghlenoid surtice and forms the boundary of the external anditury meatus. The juginl is small and forms only the middle of the jugal areh, thengh it sends back a prolongation beneath the zygumatic process of the squanosil as firr as the grlenoid surfice. 'There is no condylar foramen.

'The Mundible (figs. 2 and 3). - The horizontal ramus is very massive owing to the sreat size of the molar teeth. 'The symphysial regrion is short and spout-like, and is prolonged downwards into a short bhunt process, the last remuant of the immensely prolonged symphysis fonnd in the form next to be described. The ascending ramus

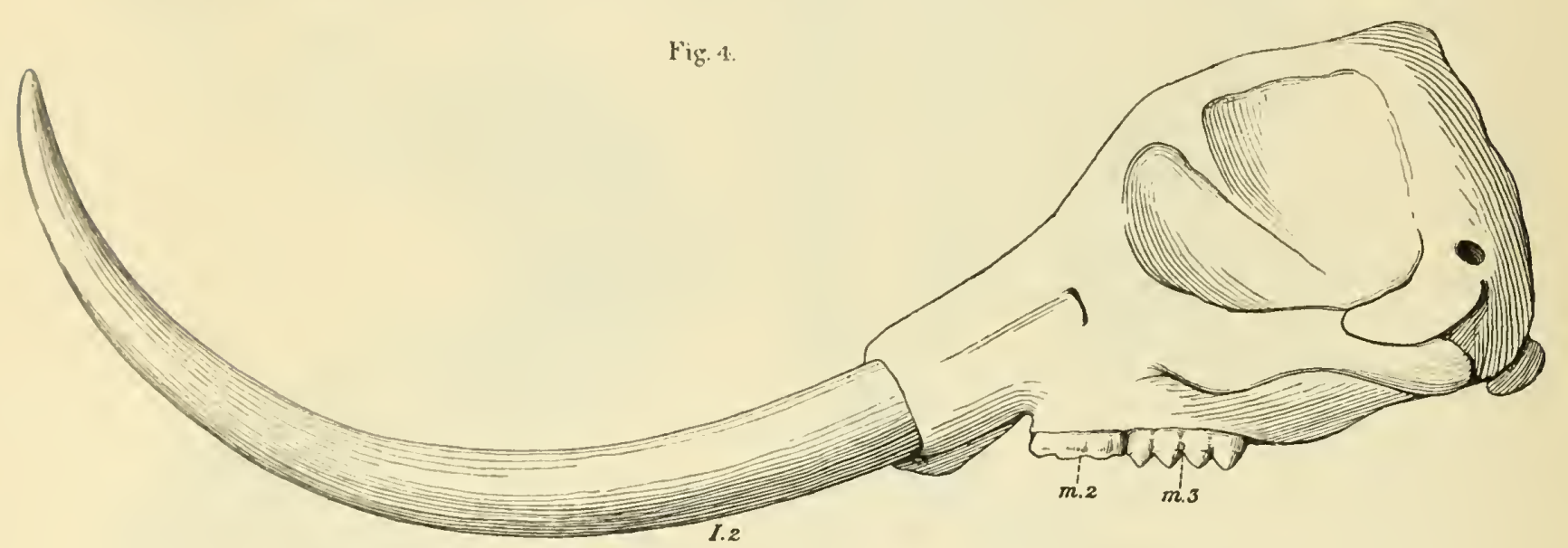

Fig. 4.-Skull of Mustodon americanus, Cuvier. Pleistocene. N. Americil.

shopes somewhat forwards and terminates in a rounded articulation; the coronoid is short and does not rise as high as the articulation, and its anterior horder arises on the outer surfice of the jaw in front of the hinder extremity of the molar series. The teeth of Elephas are so well known. that any detailed description of them is mnecessary, except so far as is needful for comparison with the earlier types.

'There is a large pair of tusk-like upper' incisors (1.2) which are homologous with the second pair of the full mammalian dentition; the dentine presents the peculiar "engine-turning " characteristic of elephant ivory; there is a small enamel cap lost through wear at an early age. The permanent incisors are preceded by a pair of milk teeth shed very soon. There are during the animal's whole life six pairs of cheek teeth in the upper jaw, of which the anterior three are milk-molars, never replaced by premolars. 'The succession of teeth is from behind, the whole series moving slowly' forwards and the anterior worn teeth being shed as the hinder ones come into pusition, and the true molars are so large that never more than portious of two on either side are 
in use at the same time, and late in life the posterior molars alone remain. The individual teeth are extremely complex in structure, each consisting of a number of transverse plates united in a common investment of cement; the plates are extremely liypselodont and increase in number from before backwards; thus in the Indian elephant the first milk-molar has four plates, while in the last true molar there may be as many as twenty-four. In the lower jaw the number and character of the teeth and their mode of replacement are the same.

The essential peculiarities of the elephant's dentition, therefore, are :-

(1) The absence of vertical successors to the milk-molars.

(2) The gradual forward movement of the series.

(3) The increase in the size and complexity of the teeth from before backwards.

(4) The lophodont and hypselodont character of the teeth

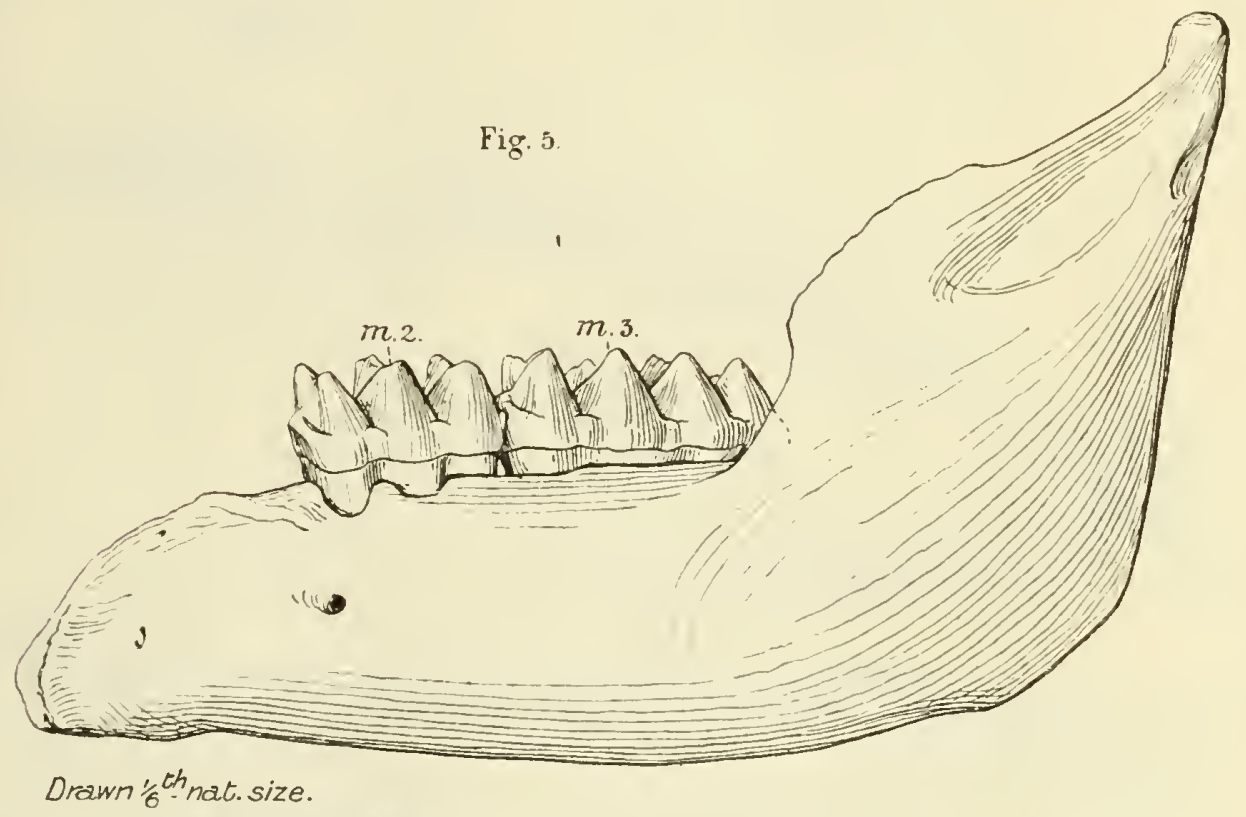

Fig. 5.--Mandible of Mastodon americamus, Cuvier. Pleistocene. N. America.

\section{Tetrabelodon angustidens, Cuvier sp.}

The Skull (figs. 6 and 7).--Unfortunately I have only been able to examine a much crushed skull of this species, but with the assistance of photographs of specimens in the Musée d'Histoire Naturelle at Paris, kindly supplied by Professors GaudrY and Marceldin Boule, it has been possible to make out the main points.

The occipital region is only a little less elevated and expanded than in Elephas; this is what might be expected, since in this animal, in addition to large tusks and the proboscis, there was also the weight of the greatly elongated mandible to be supported. It seems, however, that the development of cells in the cranial bones is somewhat less than in the recent type, and the skull is rather longer in proportion to its height, so

VOL. CXCVI.-B. 
that it rlifies a litte less than that of Elepleres fiom the ordinary proportions of the mommintian skull. At thr sime time the fircial region is almost exactly as in Elephas. 'l'he maxillas he rason of the more bachychost character of the cheek-teeth are not so decp as in the elephant, hut are still very lange owing to the great size of the molats and to their mole of replacement from hehind; anteriorly the maxillae send forwarl processes beneath the premaxillae, thus helping to support the tusks, of the alverti of which they may form the hinder edere. In the zysomatic arch the jugal porhaps extends slightly farther forwarl than in Elephas, at least ventrally. In short, the stull of 'Tetrabelodon is exsentially similar to that of Elephes.

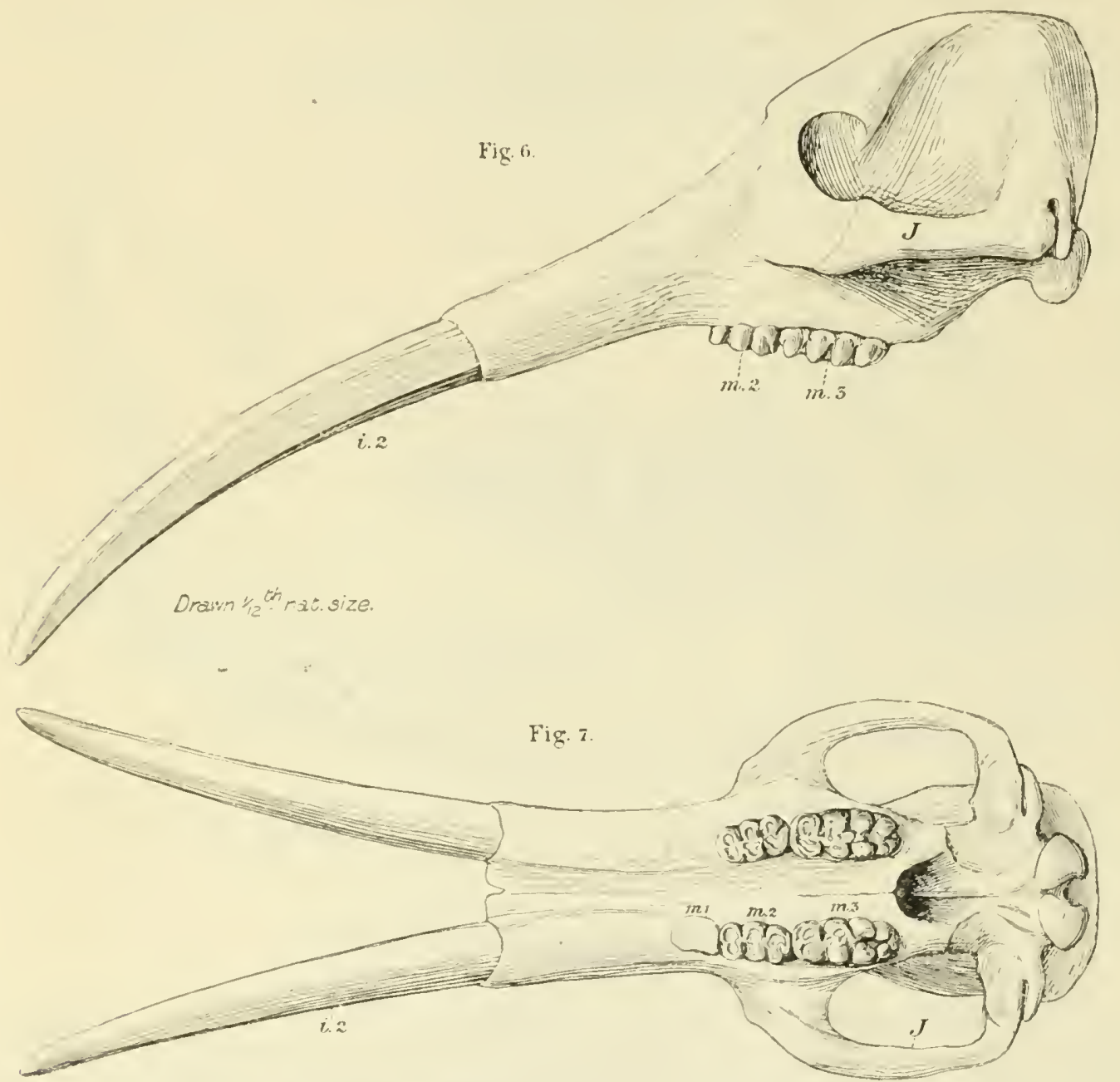

Figs. 6 and T.--Skull of Tetrabetomen ungustidens, Cuvier sp. Lower and Middle Niocene. Europe.

'l'he Mcundible (figs. 8 and 9).--It is in the mandible that the most remarkable divergence fiom lilephas is found. The symphysial region is enormously elongated anrl its upper surface deeply concave from side to side, forming a spout-like channel, the sides of which are former by the edentulous alveolar horder. The channel is nanow posterinly but widens out in front, and its concavity is continued forward 
by the upper surface of the pair of procumbent lower incisors which are in close contact with one another, at least through the greater part of their length. 'The horizontal ramus behind the symphysis is not so deep in proportion to its length as in Elephas. The angle is rounded and the hinder border of the ascending ramus slopes backwards and terminates above in a transversely elongated articulation, convex in all directions. 'The anterior border of the ascending ramus rises on the outer surface of the jaw in front of the hinder end of the alveolar border, so that in a side view the last molar is more or less concealed by it, but owing to the forward morement of the tooth
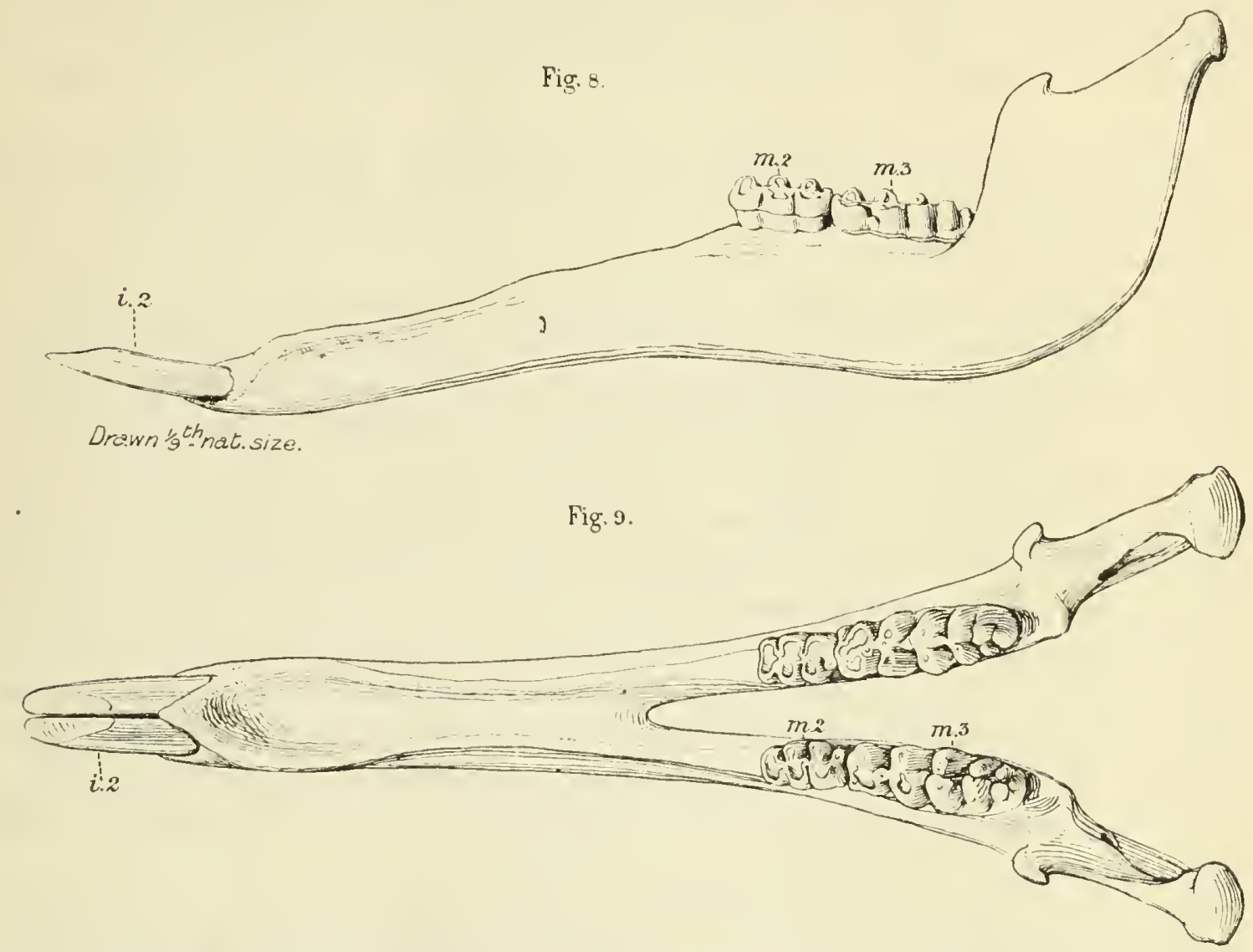

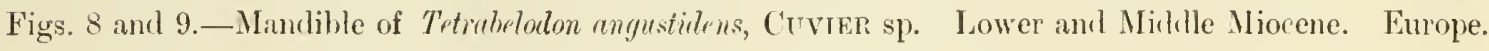

series the relative position of the teeth and the ascending ramus changes. There is a small coronoid process which does not rise so high as the articulation.

The Teeth.-The dental formula is I. $\frac{1}{1}$, Pn. $\frac{2}{2}$, M. $\frac{3}{3}$.

Upper Teeth. - The upper incisors (figs. 6 and 7 ) form a pair of large tusks differing from those of Elephas in the following points:-(1) They are straight and decurved, often to a considerable extent; (2) they are usually more or less oval in section, the long axis of the oval being antero-posterior; (3) there is a band of enanel on their outer fice, extending fiom root to tip. 
'There are three milk-molars, the hinder two of which are replaced by premolan's in the ordinaly wity, i.e., fiom beneath.

'The first and second milk-molars are bilophodont, each ridge consisting of a pair of tubercles; in the second (11.m. 2) the cingulum forms a ridge at each end of the tooth. 'I'he thirk (111.11. 3) is trilophorknt with an anterior and a posterior rielge of the cingulum; this tooth remains in use some tine after the first true nolar has come into wear, the last two milk-molars are replaced by premolas, the anterior of which eonsists of a harge anterior eusp with a smaller one internal to it, and a talon of two ar three small tubercles. 'The posterior premolar (Pm. 4) is quadritubercular, the ensps forming two crests. Both the premolars seen to be shed very soon, probably because the development of the large posterior molars leads to a forward novement of the series.

The first and second true molars are trilophodont, the cingulum forming a small talon. 'The last molar consists of three ridges and a large talon consisting of three or four tubercles.

The molars are bunolophodont, each trinsverse crest consisting of a number of distinct tubercles and being primarily divided into an inner and an outer half by a longitudinal fincow more or less clearly defined. In the upper teeth the onter half is the higher and is composed of two transversely placed tubercles, so closely united that they are often difficult to distinguish, and when worn the division between them may be completely obliterated. 'The inner half of the crest consist of a main tubercle to the :untero-externil and postero-internal sides, a pair of accessory tubercles are usually attached so that in wear the inner lobe gives a trefoil or V-shaped surface, the apex of the $\mathrm{V}$ being turned to the inner side of the tooth. In the intermediate molars the anterior accessory cusp of the anterior lobe is united with the anterior cingular lirlge, while the posterior accessory cusp of the hinder lobe is united with the talon formed by the cingulum; it is from a succession of such talons that in the later forms, the additional transverse crests of the molars seem to have been developed. The talon of the posterior molar consists of several cusps.

Lower Teeth (figs. 8 and 9).-Of the three milk-molars the anterior one is a small blunt single-cusped tooth; the second is bilophodont, each ridge consisting of two tubercles; there is also a small cingular ridge in frout and a much larger one posteriorly ; the third is trilophodont with a cingulum anteriorly and posteriorly.

The first premolar has a large anterior tubercle and tubercular talon; the second is bilophodont.

'The first true molar is trilophodont with a small ridge of the cingulum in front and a much larger talon-like one behind. 'The last molar has four transverse ridges and a talon.

In the details of their structure the lower molars are like the upper ones reversed, that is to say, the outer side of the lower teeth corresponds to the imner side of the upper.

Comparing Tetrabelodon with Elephas we find that, so far as the skull is concerned 
the differences are not great, the same mechanical conditions having existed in both forms. In Tetrabelodon the upper tusks are somewhat less unlike ordinary incisor's than in Elephas, in being curved downwards and in bearing a continuous band of enamel on their outer face. As in Elephas they are separated by a considerable interval at their alveolar ends and diverge widely distally.

It is in the mandible that the greatest differences between the two genera are found. In Elephas the symphysial region has undergone reduction to such an extent that it forms merely a very short downwardly directed spout-like projection. In T'etrubelodon, on the other hand, the most remarkable condition of things prevails (se' figs. 8 and 9). The enormously elongater symphysial region bearing a pair of procumbent incisors, projects far beyond the premaxillie and between the divergent upper tusks (see figs. $(6$ and 7 ), with which the lower incisors camot have been in contact at any time; nevertheless, these lower teeth bear on their extremities flat surfaces of wear, both on their upper and lower sides, a condition that can only be accounted for by supposing that they were employed for digging and rooting in the earth. The great length of the mandible, combined possibly with a somewhat longer neck than is found in Elephas, rendered it possible for this animal to reach the ground with its lower incisors. No doubt the portion of the mandible projecting beyond the upper jaw was covered by a sort of proboscis formed by the combined nose and upper lip (compare figs. 7 with 9 and 6 with 8); the extremity of this must have been more or less prehensile and capable of thrusting the food, rendered available by the action of the incisors, into the channel formed by the symphysial region of the mandible. Subsequently, it must be supposed, that owing to some change in the nature of the food and probably also to the increased efficiency of the end of the proboscis as an organ of prehension, the mandible became shortened so that it was no longer possible for the animal to reach the ground with its lower incisors, and when this happened the elongated symphysis would not only cease to be of any service, but possibly even prove a disadvantage as interfering with the free action of the proboscis, and therefore it was rapidly lost. 'This may account for the fact that some species of Mastodon (e.g., M. americanus, see fig. 5), but little advanced beyond Tetrabelodon angustidens in the structure of their molars, have the symphysis nearly as short as in Elephas, the reason apparently being that while in the case of the molars the increase of efficiency was gradual, in the case of the shortening of the symphysis and the projecting incisors there was a sudden transition from utility to uselessness or worse. Tetrabelodon seems to represent the stage at which the length of the mandible culminated, for it is an animal of much the size and build of the elephant and yet could reach the ground with its lower incisors. The above explanation of the possible mode of origin of the trunk in the Proboscidea was in part, so far as the main points are concernerl, suggested to me by Professor E. R. Lankester. 


\section{I'eleomastodon beadnelli, AxDrEWs.**}

'The skull (figs. 10 and 11). - Unfortunately no prerfeet specinen of the skull has yot been found, and the most complete example wants the whole of the cranial, and most of the fircial regrion; fiom this the following points cam be determined. Owing to the very biachydont character of the molars, the maxille are low and their zygomatic processess rise a rery short distance above the alveolar border, and over the second true molat. The jugal extends forwards and is a much more important factor

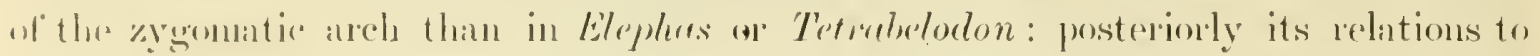

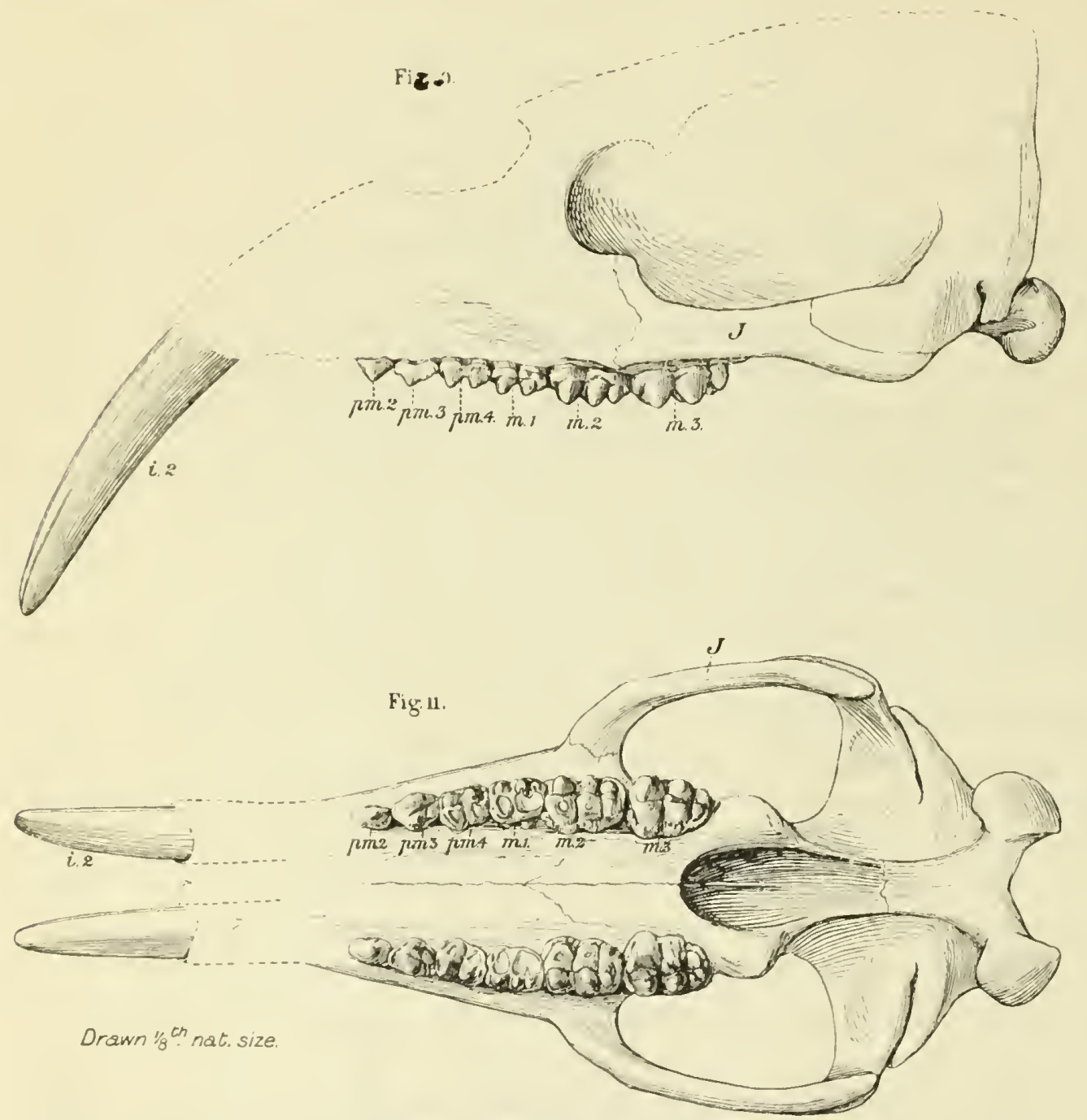

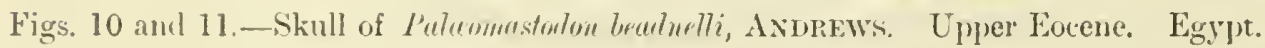

the squamosal are the same as in those genera. The glenoid surface is like that of Eleplires: there is no post-glenoid process, but a post-tympanic flange of the squamosal 
is in contact with the hinder border of the articular surface and helps to enclose the external auditory meatus, just as in the elephants. The axis of the basis crenii is parallel with that of the palate; the palatines, pterygoids and alisphenoids are much as in Elephas, but the basis cranii is more elongated and the occipital condyles are more prominent.

The Mandille (figs. 12 and 13).-The symphysis of the mandible is greatly elongated, but still to a less degree than in Tetrabelodon. It is somewhat decurved, and its upper surface forms a spout-like channel, which is continued forward by the procumbent and spatulate incisors (figs. 12 and 13). The angle is more prominent and less rounded than in Tetrabelodon, and the ascending ramus slopes backwards to a less degree. The coronoid border rises fiom the outer surface of the jaw opposite the last molar.
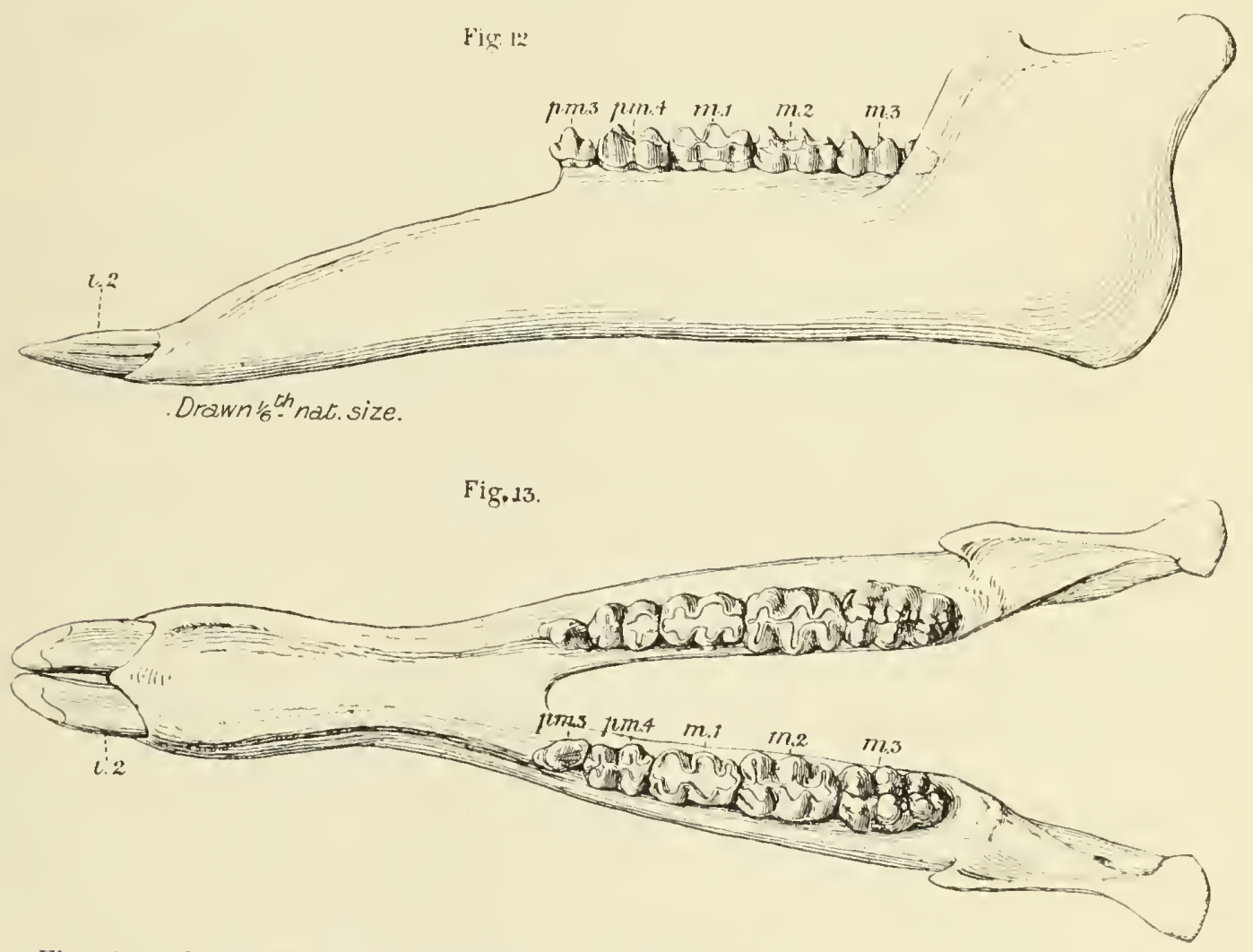

Figs. 12 and 13. - Mandible of Puldom storlon beardnelli, Andisws. Upper Eocene. Egypt.

The Teeth.-The dental formula is I. (?) $\frac{1}{1}$ C. $\frac{0}{0}:$ Pm. $\frac{3}{2}:$ M. $\frac{3}{3}$.

The upper incisors (figs. 10 and 11) were laterally compressed tusks, bearing a broad band of enamel on their outer surface and being downwardly directed It is not known whether any trace of incisors, other than the tusks, existed. The anterior upper premolar (Pm. 2) is a blunt simple cone with a slightly developed cingulum. The next (Pm. 3) consists of a large outer cone and a smaller inner one arranged 
transtersely, there is also a small inner cone behind the chictome. The cingulum is linily wall developed anel forms a small prominence both in fiont and behind. The last premolan (1'm. 4) is bilophodent, each riflge consisting of a pair of tubercles. 'l'he postero-internal cusp) is contimued backward into a small talom-like portion of the ciminlun!n.

The first true molar (M. I) is tribphodont, the iunce cusp of each rielge is the larger and most worm, tho onter is the higher ; the internal cusps tends to unite longitudinally in weal. 'l'hre seomel molar (N. 2) is much larger than M. I, the surlden increase in size being most striking; its structure is similar to that of the tooth in fiont; the postero-internal cusp) is muterl to the talon-like cingulum. 'The posterior molan (M. 3) is similar in most respects to M. 2, hut the hind lobe is much smaller, so that the tooth is actnally simplen than that in fiont of it.

The Lower. Dentition.- The single pair of lower incison's are in close contact along their straight innel borter's, and their concave upper sunface forms an anterior probugation of the spout-like symplysis. 'The upper surfice of their anterior and antern-external borders is comsiderably worm.

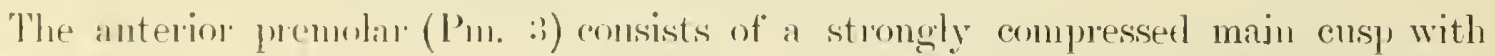
small accessony cuspes in front and behind. 'The last premolar (Pm. 4) is a narrow bilophodont tonth, atoh rirlge consisting of a pair of cusps. 'There are also small accessory cusps on the anterior and posterion borlems of the tooth. The first molar is is small trilophodont tooth with a small talon. 'The second molar (M. 2) is much larger, but is likewise trilophodont; there is a small anterior cusp connected with the antero-external main cusp, and also a small posterior talon connected with the postero"xternal main cusp. 'The posterior molar is similar but the talon is considerably larger.

Palcomastodon is more primitive than Tetrabelodon in the following points. The basis manii and the facial region of the maxilla are longer; the zygomatic arch is larger and the jugal not only takes a greater share in its composition but also extends farther forwark. In the mandible the symphysis is not so extremely elongated, and the lower incisors are more normal and less tusk-like. It is in the cheek-teeth, however, that the more generalised character of Palcomastodon is most manifest. Thus the molars anel premolars are all in wear at the same time and their morle of succession is ahnost as in ordinary Ungulates, such as the pig. The premolars replace milk predecessors, and the molars come into use one after the other in the usual way, the first molar being always the most worn. As to the structure of the individual teeth, it may be silid that they are still more brachydont than in Tetrabeloclon, the main tubercles of the transverse ridges more distinct fiom one another ant the accessory tubercles less developed.

Ln botlı genera the first and second molars are trilophodont, but in Tetrabelodon the last molar is much the more complex in both upper and lower jaws (see figs. 7 and 9). 'The sudden increase in the size of the last twomolars in P'alcomastodun seems 
to be the first indication of the great relative magnitude they are destined to attain in the later forms. The form of the atlas vertebra in Palcomcstodon indicates that the neck was longer than in the later forms. The limb bones, as far as known, differ from those of Elephas in little except size.

\section{Mceritherium lyonsi, ANDREws.*}

The skull, mandible and dentition of Moritherium are fairly well known and have been briefly described and figured by me. Here, only the points necessary for the purpose in hand need be mentioned.

The Skull (figs. 14 and 15).--The occipital surface is very wide and its plane nearly vertical. The foramen magmum is large, and the occipital condyles prominent and almost pedunculate. The zygomatic process of the squamosal is very massive and prominent, and the glenoid surface is a broad and ill-defined slightly concave area ; there is no post-glenoid process, but a broad post-tympanic flange is closely applied to the hinder edge of the glenoid surface and encloses the large external auditory meatus precisely in the manner characteristic of the later Proboscidea. The parietals form most of the cranial roof, and like the cranial portion of the squamosals are greatly thickened, so that in one species (Maritherium gracile, AxDr. $\dot{\dagger}$ ) there is a distinct inflation of the hinder portion of the sides of the skull, possibly the first indication of the enormous development of diploë found in the later forms. The frontals seem to have been small, and there is no well-defined post-orbital processes. The nasals also were small and the nasal opening very large; the form of this opening, together with the grooving of the upper surface of the large premaxillie, seem to point to the existence of some kind of small proboscis-like structure. The premaxillie bear the alveoli of three pairs of incisors. 'The second pair are greatly enlarged, trihedral and downwardly directed tusks, the roots of which run back into the maxillie and probably grew from a persistent pulp. The maxilla bear sockets for a pair of canines and six pairs of cheek-teeth; there is a prominent zygomatic process which is to a great extent overlapped by the anterior portion of the jugal, which here forms a large part of the zygomatic arch and extends back beneath the zygomatic process of the squamosal as far as the articulation for the mandible.

The Mundible (figs. 16 and 17). -The horizontal ramus of the mandible is very stout, and its outer sunface rounded from above downwards; anteriorly they unite in a massive symphysis, the upper spout-like surface of which is continued forward by the procumbent incisors, of which there are two pairs, the median of which are small and laterally compressed teeth, the outer, large tusks. The ascending ramus is broad and is inclined somewhat forward; its anterior border rises from the outer surface of the horizontal ramus in front of the hinder end of the molar series as in other

* 'Geological Magazine,' dec. IV, vol. 8 (1901), p. 403.

†' 'Geological Magazine,' lec. IV, vol. 9 (1902), p. 292.

VOL. CXCVI. - D. 
Probuscideal. 'The comonod rloes not rise above the articnlation, which is a transwersely elongated condyle. 'The anghe is broal and rounded.

'The Dentilion (figs. 1.4-17). -There are three pairs of upper incisors; the first are compantively small teeth in close contact in the middle line; the second are large downwardly directed trihedral tusks which, as previously mentioned, probably grew from persistent pulps; the thind pair of incisors and the canines were small teeth represented
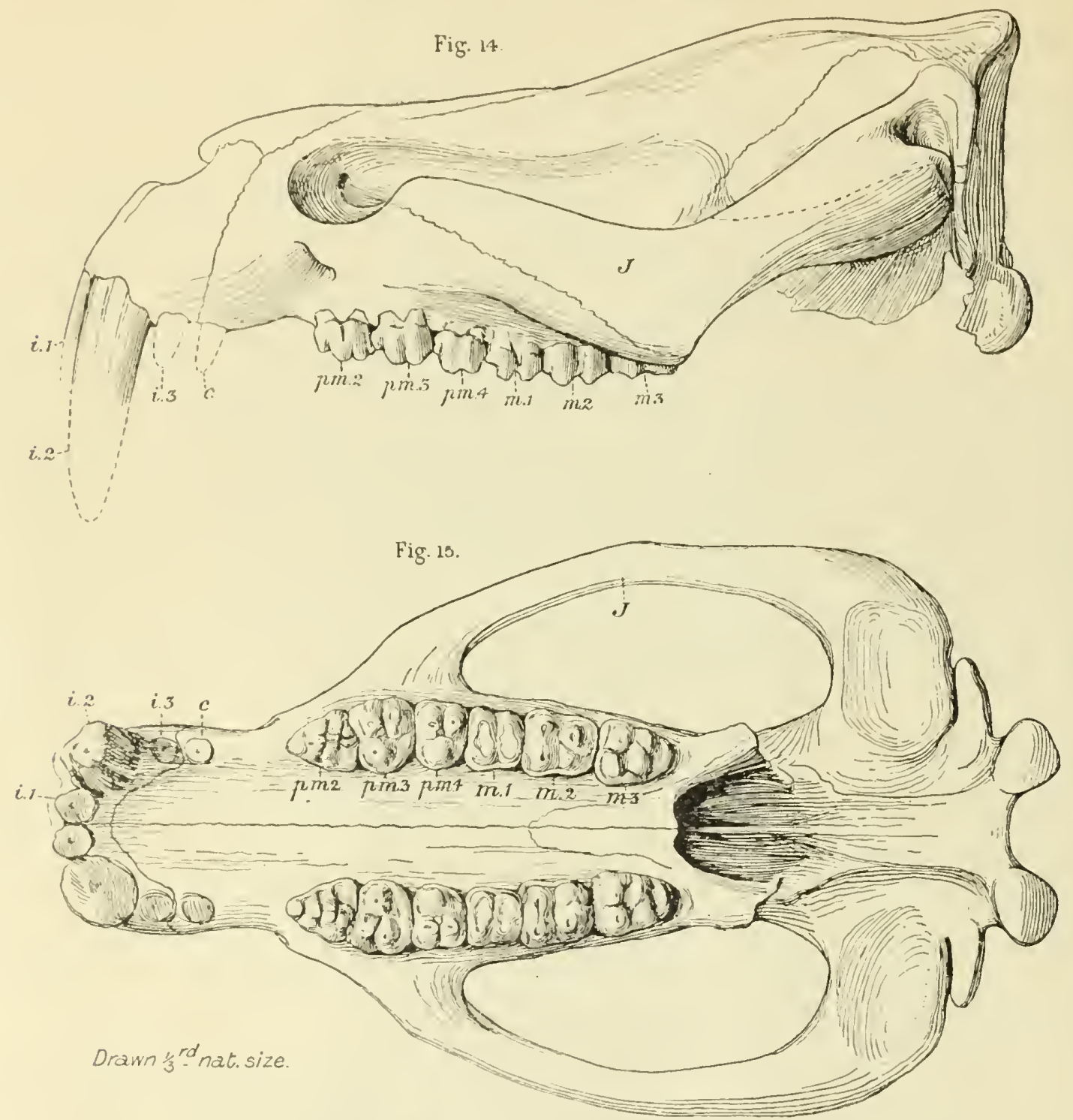

Skull of Mcritherimm lymsi, Axprews. M. Eocene. Egypt.

in all the arailable specimens by the alveoli only. 'The first premolar is wanting', the second (Pm. 2) is triangular in outline, the crown consists of an outer row of cusps and a postero-internal shelf-like projection (see fig. 15). The next tonth (Pm. 3) consists of a pair of transversely arranged anterior cusps and a postern-internal one, internal to which is a small shelf-like projection. The next premolar (Pm. 4) is 
similar. The two anterior molars are bilophodont, each transverse crest being composed of a higher and more pointed outer cusp and a blunter and more worn inner one. The postero-internal cusp is also prolonged backward into a small blunt lobe which, when worn, gives rise to the pattern shown in the figure (fig. 15); the last molar is bilophodont and has a small talon.

The lower incisors have already been referred to. The cheek teeth are six in number, the first premolar being wanting. The second premolar is a comparatively small tooth, and is compressed from side to side. It consists of a large anterior cusp

Fig. 16.
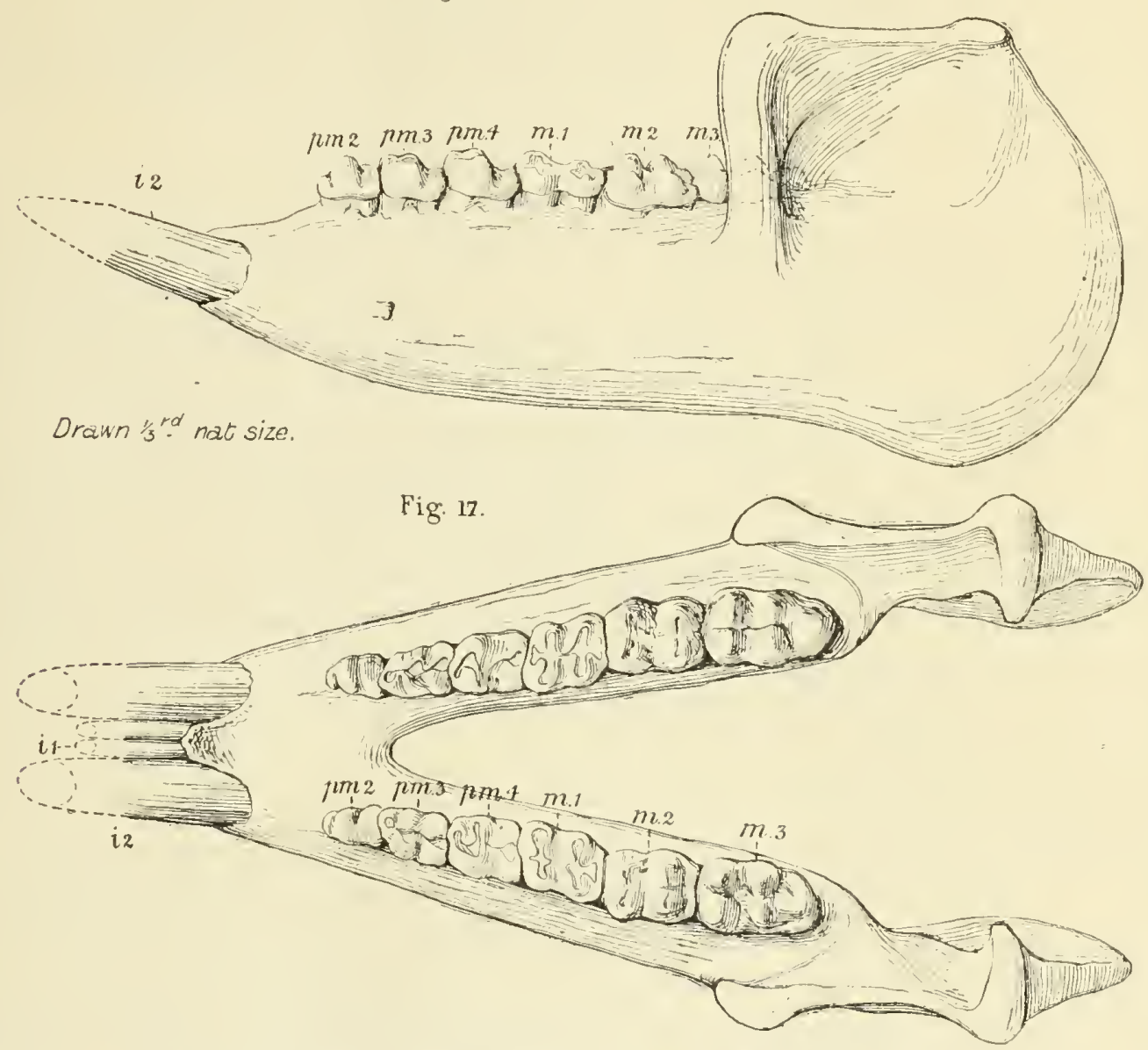

Mandible of Moritherium lyonsi, ANDREws. M. Eocene. Egypt.

behind which is a talon of considerable size. 'The third premolar is much larger; it consists of a high anterior portion and a posterior talon. The anterior part is composed of three cusps, one of which forms the antero-internal angle of the tooth, while behind this the other two are arranged transversely. The talon has a median ridge which rises posteriorly into a tubercle. The fourth premolar the anterior cusp is less distinct, but those forming the transverse ridge are better developed, especially the imner one. The cusp on the talon is also larger than on the tooth in front. The first true molar is bilophodont, each ridge consisting of two almost distinct tubercles. The cingulum 
forms a small shelf-like ridge at the anterior end of the tooth and a larger one behind; in weal this latter becomes connected with the worn surface of the postero(xternal cusp), and it forms the rudinent of a third ridge. The next molar is sinilar. The last is likewise bilophodont, hut has also a lange tuberculate talon.

The relatively primitive chander of Mariherium is shown by the fiact that the skinll fresents no very striking preuliarities beyond the forward extension of the maxille and the great thickness of the crmial lomes. In the mandible the massive symphysis is little elongated. In the upper jaw only one tooth (Pn. 1) of the finll Eutherin dentition is wanting; in the mandible three (1. 3, C. and Pm. I) hare been lost. 'The incisors are becoming specialised, but the premolars and molars are of a simple type, though they already show a tendency to increasing specialisation along the lines subsecpuently pursued throughont the group.

The discovery of an eally and compratively generalised type like Maritherium niaturally raises the question of the relationship of the Proboscidea to the other mammals, and although at present it is not possible to arive at any definite conclusion as to the origin of the gromp, the view put forward by BuninviLue and others that they may be related to the Sirenia receives some support. It must be said, however, that several writers* have stremonsly opposed this opinion.

The relationship between the two groups must necessarily be a remote one since a Sirenian (Eosiren), very little less specialised than Manatus or at any rate than Hulitherium, occurs associated with Mceritherium, so that a common ancestor of the two groups cannot have existed later than the Lower Eocene. Nevertheless, the following character's are common to the two :-

(1) Placenta non-deciduate and zonary.

(2) Pectoral mamme.

(3) Abdominal testes.

(4) Bifid apex of heart.

(5) Absence of the condylar foramen, ahays in the elephants and gencrally in the Sirenia, where, however, it may be bridged over by a thin strand of bone.

(6) 'The bilophodont character' of the molars with a tendency to the formation of an additional lobe fiom the posterior part of the cingulum (talon). The molar's of some Sirenia are extremely like the anterior molars of Moritherium.

(7) In both groups the molar series moves forward in the jaws throughout life, the anterior worn teeth being shed while fiesh ones come into use behind. In the Sirenia this is effected by the continuous addition of teeth similar to the other molars, while in the Proboscidea no fresh teeth are added but the individual molars become longer and more complex through the addition of finther transverse crests to their posterior ends.

* See for instance 'T. Gild, "On the Affinities of the Sirenians," 'Proc. Acad. Nat. Sci., Philadelphia, 1873 , p. 262 . 
(8) The humerus of Mceritherium is extremely like that of a Sirenian. Many of the above-mentioned characters are by themselves of little import, but the coincidence of so many points of similarity seem to render the existence of a common ancestry for the two groups at least probable.

\section{Summary.}

The changes undergone by the skull, mandible and dentition in the Proboscidea in passing from the Eocene to the recent types, may be summarised as follows :-

The Skull.-Owing to the increase in the size of the tusks and to the presence of the proboscis the facial region of the skull becomes shortened, and at the same time the premaxillæ become wider. The presence of the proboscis also accounts for the position of the external nares. The demand for a greater surface of attachment for the muscles, supporting a skull rendered heavy by the tusks and trunk, is met by the great development of the diploë in. certain of the cranial bones, resulting in the enormous expansion of the forwardly sloping occipital surface. The maxillæ become greatly enlarged pari passu with the increase in the size and degree of hypselodonty of the molars. At the same time the zygomatic arch becomes weaker and the jugal takes a smaller share in its composition.

The Mandible.-The mandible is at first short and stout with a massive symphysis. Afterwards it becomes more and more elongated as the stature of the animals increases; the elongation is for the most part effected by the lengthening of the symphysial region, but the rotation backward of the ascending ranus tends to the same end. The prolongation of the mandible beyond the premaxillæ must have been covered by a proboscis-like structure composed of the upper lip and nose, probably more or less prehensile at its extremity. The lengthening of the mandible seems to have reached its naximum degree in the Middle Miocene, after which for some reason or other it again became shortened by the reduction of the symphysis, while the fleshy and now mobile proboscis was left behind as the sole organ of prehension.

'The Dentition.-In the upper jaw the chief' changes are the loss of I. 1 and I. 3, and the great increase in size of I. 2, which finally forms the great tusk characteristic of the later Proboscidea. The canines are soon lost. In the early forms some at least of the milk-molars are replaced by premolars in the usual manner, and these teeth remain in wear simultaneously with the true molars, but in later forms no vertical succession takes place, and as the milk-teeth are worn they are shed, being replaced from behind by the forward movement of the molars. Of these also the anterior may be shed, until at length, in old individuals of the later types, the last molar is alone functional. The gradual increase in the complexity of the Proboscidean molars is one of their most striking characteristics. All stages are to be traced between the simple brachydont bilophodont (quadritubercular) molars of Muritheriun, 
to the extrandinarily complex type of tooth found in Elephas. Thus in Prelromastorion the molirs are trilophodont, and the sime is true of the first and second molars of Totrubelodon, in which, however, the last molar is complicated by the addition of further transverse crests. In the Stegodonts of the Siwalik Hills a further increase in the number and height of the crests takes place, and the whole crown of the tooth is more or less covered with a thick coat of cenent. Still later the transverse crests become highly compressed lamina united by cement, and in Elephas maximus and li. primigcrius there may be as many as twenty-seven of them.

In the lower jaw the median and onter pairs of lower incisors (I. 1 and 3 ) were soon lost, but the second pair (I. 2) remained functional, and heing prolonged in the direction of the mandibular symphysis helped to lengthen the animal's reach. After the symphysis became shortened, the lower incison's were in some cases (c.g., Mastodon cmericunus) retained, but the irregularity of their occurrence in known specimens shows that they were probably functionless. In Elephas no trace of the lower incisors l'emains.

'The chinges molergone by the lower molars are similar to those of the upper molin's. 


Sold by Harrison and Sons, St. Martin's Lane.

Demy 8vo, pp. 427. Price 12s. 6\%.

\section{THE RECORD OF THE ROYAL SOCIETY.}

Sccond Edition. 1901.

Containing an Account of the Foundation, History, \&c., of the Society, with a Chronological List and Alphabetical Index of the Fellows from the Foundation.

Ready Shortly. Demy 8vo, pp. 265. Price 5s.

THE YEAR-BOOK OF THE ROYAL SOCIETY, 1903.

Principal Contents:-List of Fellows, Committees, \&c.; Statutes and Regulations; Business of the Society during 1902, including Anniversary Meeting with President's Address, Council's Report, and Treasurer's Accounts; Arrangements for 1903; Obituary Notices of Fellows deceased.

PHILOSOPHICAL TRANSACTIONS.

Srerifs A. Containing Papers of a Mathematical or Physical Character.

Vol. 199 (1902), Price $£ 1$ s.

Vor. 200 (1903), Price $£ 23 s$., with 39 Plates.

SERIEs B. Containing Papers of a Biological Character.

Vol. 191 (1901), Price $£ 3$, with 49 Plates.

Vol. 195 (1903), Price $£ 17$ s., with 16 Plates.

Now Ready. Price 8s.

Royal 4to. 112 pages, with Map and Illustrations.

\section{MAGNETIC AND METEOROLOGICAL OBSERVATIONS} IIADE BY

THE "SOUTHERN CROSS" ANTARCTIC EXPEDITION, 1898-1900,

Under the direction of C. E. Borcugrevink.

Published by the Royal Society of London, and sold by Harrison A.Y. Sons, St. Martin's Lane.

Fellows of the Royal Society can obtain copies gratis, on application.

Published by Kegax Paul, Trexch, Trübner, and Co.

A few copies at the reduced price of $£ 1$ 1s. (published at $£ 3$ ).

Royal 4to, pp. iv.-936, cloth. With 51 Lithographic and Photographic Plates.

A MONOGRAPH OF THE HORNY SPONGES.

BY K. VON LENDENFELD.

A further reduction of priee to Fellows of the Royal Society.

Published by Kegan Paul, Trexch, Trübser, and Co.

In 1 vol., 4to. Pp. 500. With 6 Chromolithographs of the remarkable Sunsets of 1883 and 40 Maps and Diagrams.

THE ERUPTION OF KRAKATOA AND SUBSEQUENT PHENOMENA.

Report of the Krakatoa Committee of the Royal Society.

EDITED By G. J. SYMONS, F.R.S.

Price 30s. To Fellows of the Royal Society and Royal Mctcorological Society, 20 s.

Published by Kegan Paul, Trench, Trübner, and Co.

Royal 4to, pp. xiv. -326 , cloth. Price $21 s$.

OBSERVATIONS OF THE INTERNATIONAL POLAR EXPEDITIONS, $1882-1883$.

FORT RAE.

With 32 Lithographic Folding Plates.

A reduction of price to Fellows of the Royal Society.

Continental Agents for the publications of the Royal Socicty, Messrs. FriedLÄnder and Sos, Berlin. 


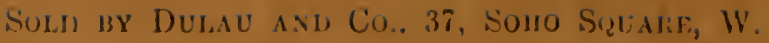

RECEN'T PAPERS IN THE 'PHLLOSOPHICAL TRANSAC'IIONS,' $1902-1903$.

\section{Sirics. A.-Mathenatical and Physical.}

A. 334. On an Approximate Solntion for the Bending of a Bean of Rectangular Cross-Section under any System of l.oud, with Special Reference to Points of Concentrated or Discontinuous Loading. By L. N. (1. Frı.ov, B.A. (Cantah.), M.A., B.Sc. (Lonrl.), King's College, Cambridge, Fellow of University College, London, and 1851 Exhibition Science Research Scholar. Price 5s.

A. 335. On the Vilurations and Stability of a Gravitating Planct. By J. H. JEANs, B.A., Isaac Newton Stndent, ind Fellow of Trinity College, Camlnridge. Price 1s. 6l.

A. 336. (n the Formation of Definite ligures ly the Deposition of 1)nst. By W. J. R(sskid, I'h.I)., F.R.S. Price 2s. Grl.

A. 337. The Spectrum of y Cygui. By Sir Nomman Lockyle, K.C.B., F.R.S., and F. W. Baxaxdal.t, A.R.C.Se. Price 2s. 6\%.

A. 338. Quatemions and Projective (Geometry. By Professor Cinarles Jaspen Joly, Royal Astronomer of Ireland. P'rice 5.s.

A. 33\%. The Differential Invariants of a Surface, and their Geometric Significance. By A. R. Forsyth M.A., Sc.ID., F.R.S., Sadlerian Professor of Prure Mathenatics in the Universily of Cambridge. Price 3s. 6ll.

A. 340. Un the Laws Governing Electric Discharges in Gases at Low Pressures. By W. R. Carr, B.A., Post-Gradnate Student, University of Toronto. Price $2 s$.

A. 341. On the Dependence of the Refraetive Index of Gases on Temperature. By Georise W. Wal_ker, M.A., A.R.C.S., Fellow of Trinity College, Cambridge. Price 1..6 6d.

A. 34य. Solar Eclipse of 1900, May 28. General Diseussion of Spectroscopic Resnlts. By J. Eversined, F.I.A.S. Priee 3..

A. 343. The Electrical Condnctivity imparted to a Vacuun by Hot Conductors. By O. W. Richardson, B.A., B.Sc., Fellow of Trinity College, Cambridge. Price 3s. 6d.

\section{Series B.-Biological.}

B. 210. The Strncture and Derelopment of the Stem in the Pteridophyta and Gymmosperns. By EDWAIID C. JEFrRey, Ph.D. (Harvard). I'rice 3s.

B. 211. On the Structure of the Gills of the Lanmellilmanchia. By W. ('. Rublwooy, D.Se., F.L.S., I 4 ecturer on Biology at the Medical School of St. Miny's Ilospital, London. Price 9s. 6d.

B. 212. The Development of Lichinus csculentus, together with some Points in the Development of E. miliuris and E. urutus. By E. W. MAcBribs, M.A., D.Sc. (Lond.), sometime Fellow of St. John's College, Cambridge, Stmathcona Professor of Zoology in the MIcGill University, Montreal. Price 8s. 6 $\%$.

B. 213. Title, Contents, Index, \&c., Vol. 195. Price 6rl.

B. 214. The Sect-fungus of Lolium temulentum, L., the Darnel. By B. MI. Frewan, M.S., University of Minnesota. Price 3s.

B. 215. Un the Histology of Urealo Disperse, Erikss, and the "Mycoplasm "IIypothesis." By H. Marsilali WarI, Sc.D., F.R.S., Professor of Botany in the University of Cambridge. P'rice $3 s$.

B. 216. The (Estrous Cycle and the Formation of the Corpns Luteum in the sheep. By Fraxcis H. A. Marshat.l, B.A. I'riec 4..

Cloth cases for binding the 'Philosophical Transactions' can be obtained of HARRison and SoNs, St. Martin's Lane. Price 1s. 6d. 


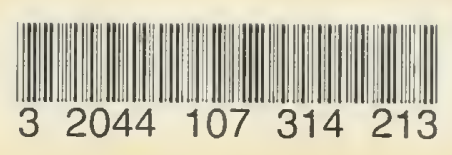


